Journal Ability : : Journal of Education and Social Analysis

Volume 2, Issue 3, Juli 2021

\title{
Upaya Meningkatkan Hasil Belajar Siswa Menggunakan Metode Field Trip Dalam Pembelajaran IPS Di SD Negeri 56 Aek Batu Kecamatan Torgamba
}

\section{Rusmawati Simamora}

SD Negeri 56 Aek Batu Kecamatan Torgamba

Corresponding Author : rusmawatisimamora645@mail.com

\begin{tabular}{|c|c|}
\hline & ABSTRACT \\
\hline & $\begin{array}{l}\text { Penelitian ini bertujuan untuk mengetahui penggunaan metode field trip } \\
\text { materi Sisitem Perekonomian Indonesia dapat meningkatkan hasil } \\
\text { belajar siswa kelas IV SD Negeri } 56 \text { Aek Batu Kecamatan Torgamba. } \\
\text { Penelitian ini adalah penelitian tindakan kelas dengan } 2 \text { siklus, setiap } \\
\text { siklus terdiri } 4 \text { kegiatan yaitu perencanaan, tindakan, observasi dan } \\
\text { refleksi yang diikuti oleh perencanaan pada siklus berikutnya dengan } \\
\text { memanfaatkan hasil refleksi sebelumnya Subjek penelitian adalah siswa } \\
\text { kelas IV SD Negeri } 56 \text { Aek Batu Kecamatan Torgamba Tahun Ajaran } \\
2021 / 2022 \text { sebanyak } 40 \text { orang. Temuan penelitian menunjukkan } \\
\text { pembelajaran IPS dengan penerapan metode pembelajaran field trip } \\
\text { dapat meningkatkan hasil belajar siswa dibuktikan dengan } \\
\text { meningkatnya hasil belajar setiap siklus yaitu dari rata-rata 67,67 } \\
\text { menjadi rata-rata } 83,19 \text {. }\end{array}$ \\
\hline Kata Kunci & Hasil Belajar, Metode Field Trip, IPS \\
\hline How to cite & (2021). Jurnal Ability, 2(3). \\
\hline
\end{tabular}

\section{PENDAHULUAN}

IPS merupakan ilmu untuk menunjang kehidupan sepanjang hayat dan mendorong peningkatan kehidupan yang bidang kajiannya memungkinkan peserta didik memperoleh jawaban atas pertanyaan dunia sekelilingnya yang menekankan pada aspek spasial, dan ekologis dari eksistensi manusia. Pembelajaran IPS bukan hanya untuk menguasai tentang pengetahuan belaka, tetapi juga untuk mampu menggunakan ilmu yang telah dipelajarinya dan membentuk siswa agar menjadi warga masyarakat yang percaya diri dalam berperan serta secara produktif (Depdiknas, 2000 : 47). pembelajaran IPS memiliki makna penting dalam pembentukan manusia yang produktif. Pembelajaran IPS berkaitan erat dengan kehidupan sehari-hari.

Pembelajaran ialah membelajarkan siswa menggunakan asas pendidikan maupun teori belajar merupakan penentu utama keberhasilan pendidikan. Pembelajaran merupakan proses komunikasi dua arah, mengajar dilakukan 
Ability : Journal of Education and Social Analysis

Volume 2, Issue 3, Juli 2021

Page : 108-115

oleh pihak guru sebagai pendidik, sedangkan belajar dilakukan oleh peserta didik atau murid. (Sagala, 2008:15). Menurut Sudjana (2004:28) “Pembelajaran dapat diartikan sebagai setiap upaya yang sistematik dan sengaja untuk menciptakan agar terjadi kegiatan interaksi edukatif antara dua pihak, yaitu antara peserta didik (warga belajar) dan pendidik (sumber belajar) yang melakukan kegiatan membelajarkan".

Jadi dapat disimpulkan bahwa pembelajaran adalah suatu upaya yang dilakukan untuk menciptakan proses belajar mengajar. Pembelajaran disini lebih menekankan pada bagaimana upaya guru untuk mendorong atau memfasilitasi siswa dalam belajar Proses pembelajaran dapat terlaksana dengan baik jika guru dapat merencanakan/ merancang pembelajaran dengan sistematis dan cermat yaitu dengan menggunakan model-model dan media pembelajaran yang tepat sehingga materi pembelajaran dapat dengan mudah dipahami oleh peserta didik. Oleh karena itu, untuk meningkatkan kualitas penyelenggaraan proses pembelajaran, guru perlu memahami hal-hal yang mempengaruhi proses belajar siswa, baik yang menghambat maupun yang mendukung.

Faktor dari dalam individu siswa juga sangat berpengaruh dalam proses belajar mengajar, seperti minat siswa dalam mengikuti proses belajar mengajar. Menumbuhkan minat belajar siswa merupakan salah satu faktor penting dalam kegiatan belajar mengajar. Tanpa adanya minat belajar, tidak mungkin siswa memiliki kemauan belajar dan dapat mencapai prestasi belajar yang optimal. Guru dituntut untuk dapat melakukan usaha-usaha dalam menumbuhkan dan membangkitkan minat belajar siswanya dalam pembelajaran. Guru seharusnya mampu menerapkan model pembelajaran yang variatif dan menyenangkan sehingga dapat menarik minat dan antusias siswa dalam mengikuti proses pembelajaran sehingga dapat meningkatkan hasil belajar. Guru harus mampu memahami model atau strategi pembelajaran yang efektif yang sesuai dengan karakteristik peserta didik sehingga pembelajaran yang diajarkan dapat mendorong siswa aktif dan mampu meningkatkan mutu dan kualitas guru tersebut.

Berdasarkan data ang diperoleh bahwa pembelajaran IPS di kelas IV masih sangat jauh tingkat keberhasilannya. Salah satu persoalan mendasar adalah banyak kalangan siswa yang menganggap bahwa belajar sebagai aktivitas yang tidak menyenangkan, karena mereka harus duduk berjam-jam dengan mencurahkan perhatian dan pikiran pada suatu pokok bahasan, baik yang sedang disampaikan guru maupun yang sedang dihadapi di meja belajar. Berbagai upaya telah dilakukan untuk meningkatkan mutu pendidikan dan 
Ability : Journal of Education and Social Analysis

Volume 2, Issue 3, Juli 2021

Page : 108-115

pengajaran IPS, guru memahami dan mengembangkan berbagai model, keterampilan dan strategi dalam pembelajaran, sehingga dapat memberikan dorongan kepada siswa untuk memperoleh hasil belajar yang optimal.

Banyak macam metode yang bisa dipilih guru dalam kegiatan mengajar, namun tidak semua metode bisa dikatakan baik dan tidak semua pula dikatakan jelek. Kebaikan suatu metode terletak pada ketepatan memilih sesuai tuntutan pembelajaran. Menurut Sumiati, dkk (2009: 92-96) dijelaskan bahwa pemilihan metode harus disesuaikan dengan: (1) tujuan pembelajaran, (2) materi pembelajaran, (3) kemampuan guru, (4) kondisi siswa, (5) sumber dan fasilitas yang tersedia, (6) situasi kondisi belajar mengajar, (7) waktu yang tersedia, (8) tempat belajar. Maka untuk menerapkan suatu metode pembelajaran yang relevan dengan situasi tertentu, guru harus memahami keadaan metode pembelajaran tersebut, baik keampuhan maupun tata caranya (Hamdani, 2012: 82).

Salah satu metode pembelajaran yang dapat digunakan dalam pembelajaran IPS adalah metode field trip. Metode field trip atau karya wisata merupakan metode pembelajaran yang menyenangkan, di mana siswa diharuskan belajar di luar kelas atau outdoor. Bukan sekedar keluar kelas lalu belajar, namun dalam field trip siswa diajak untuk melihat dan mengamati objek yang dipelajari secara langsung. Wang dan Carlson (2011) mengemukakan bahwa "A field trip is a common strategy used by educators to bring out-of-scool learning experrience into schools". Pernyataan tersebut mengandung makna bahwa field trip adalah suatu strategi umum yang digunakan oleh pendidik untuk membawa pengalaman belajar yang ada di luar sekolah ke dalam sekolah. Rusyan dalam Abimanyu (2008: 7.6) menambahkan bahwa walaupun karya wisata banyak unsur nonakademisnya, tetapi tujuan pendidikan dapat pula tercapai terutama mengenai wawasan dan pengalaman tentang dunia luar seperti tempat yang memiliki situs bersejarah, musium, peternakan atau pertanian (agro wisata) dan sebagainya. Tempat pelaksanaan field trip tidak harus tempat yang jauh, ketika tempat tersebut memiliki objek dan sumber informasi yang lengkap terkait materi pelajaran, tempat tersebut dapat digunakan sebagai field trip.

Field trip bukan sekedar kegiatan rekreasi semata, melainkan belajar dengan melihat objek secara langsung untuk mempertegas gambaran yang didapat siswa ketika di kelas. Batic (2011: 79) menjelaskan bahwa "Education field trip enable pupils to gain new experience and make them more aware of the world in which they live". Penjelasan tersebut mengandung arti bahwa field trip dalam bidang pendidikan memungkinkan para siswa untuk memperoleh pengalaman 
Ability : Journal of Education and Social Analysis

Volume 2, Issue 3, Juli 2021

Page : 108-115

baru dan membuat mereka lebih sadar akan dunia di mana mereka hidup. Pelaksanaan field trip memberikan pengalaman unik pada siswa dengan menampilkan meteri pelajaran secara nyata. Field trip menuntut guru untuk dapat merancang kegiatan pembelajaran secara jelas dan menyenangkan. Anitah (2009: 5.30) supaya field trip berjalan dengan optimal, guru harus memiliki kemampuan sebagai berikut: 1) mampu mengidentifikasi objek karya wisata yang sesuai dengan tujuan pembelajaran, 2) mampu membuat perencanaan dan panduan siswa, 3) mampu mempersiapkan bahan dan alat dalam karya wisata, 4) mampu mengontrol, memfasilitasi dan membimbing aktivitas siswa selama kegiatan dan 5) mampu menilai karya wisata.

Ada beberapa langkah-langkah yang harus dilakukan guru dalam menerapkan metode field trip pada pembelajaran. Abimanyu (2008: 78-79) menyebutkan langkah-langkah tersebut yaitu: 1) kegiatan Persiapan meliputi: merumuskan tujuan pembelajaran; menyiapkan meteri pelajaran yang sesuai silabus/kurikulum; melakukan studi awal ke lokasi sasaran karya wisata dan menyiapkan skenario pelaksanaan karya wisata, 2) kegiatan Pelaksanaan Karya Wisata Kegiatan pelaksanaan field trip meliputi kegiatan pembukaan, inti dan penutup.

Kegiatan pembukaan dilakukan di sekolah sebelum berangkat ke lokasi karya wisata atau dapat dilakukan di lokasi karya wisata sebelum turun ke lapangan. Kegiatan ini meliputi: mengingatkan kembali pelajaran yang pernah diberikan melalui pertanyaan apersepsi; memotivasi siswa dengan membuat kaitan materi pelajaran yang akan dipelajari dengan peristiwa-peristiwa yang terjadi di masyarakat; mengemukakan tujuan pembelajaran yang akan dipelajari dan kegiatan-kegiatan yang harus dilakukan untuk mencapai pelajaran tersebut selama karya wisata dan mengemukakan tata tertib selama karya wisata.

Kegiatan inti, kegiatan yang dilakukan oleh siswa saat berada di tempat yang dikunjungi. Kegiatan ini meliputi: melakukan observasi terhadap objek sasaran belajar; mewawancarai nara sumber dan mencatat informasi yang disampaikan secara lisan oleh nara sumber; mengumpulkan leaflet booklet yang ada; sesuai dengan skenario yang disiapkan guru dapat juga diselenggarakan seminar atau diskusi dengan nara sumber.

Kegiatan penutup, kegiatan mengakhiri karya wisata ini dapat dilakukan ketika masih berada di lokasi karya wisata atau setelah kembali ke sekolah, kegiatannya meliputi: menyuruh siswa melaporkan hasil karya wisata dan membuat rangkuman; melakukan evaluasi proses dan hasil karya wisata; 
Ability : Journal of Education and Social Analysis

Volume 2, Issue 3, Juli 2021

Page : 108-115

merupakan tindak lanjut berupa tugas yang sifatnya memperkaya hasil karya wisata.

Berdasarkan permasalahan diatas adapun rumusan masalah dalam penelitian ini adalah : apakah penggunaan metode field trip dapat meningkatkan hasil belajar IPS pada siswa kelas IV SD Negeri 56 Aek Batu Kecamatan Torgamba 2021/2022.

\section{METODE PENELITIAN}

Penelitian ini dilaksanakan di SD Negeri 56 Aek Batu Kecamatan Torgamba Subjek dalam penelitian ini adalah siswa kelas IV SD Negeri 56 Aek Batu Kecamatan Torgamba Tahun ajaran 2021/2022 yang berjumlah 40 orang. Sumber data dari penelitian ini adalah siswa, teman sejawat/ guru kelas, dan peneliti.

Bentuk penelitian ini adalah Penelitian Tindakan Kelas. siklus I maupun siklus II. Analisis data tes hasil belajar dilakukan dengan melakukan analisis ketuntasan belajar klasikal. Analisis data hasil pengamatan aktifitas guru dan siswa dilakukan secara deskriptif, yaitu dengan menginterperstasikan hasil pengamatan terhadap nilai-nilai yaitu sangat kurang $(0-20)$, kurang $(21-40)$, cukup (41 - 60), baik (61 - 80), dan sangat baik (81 - 100). Indikator keberhasilan PTK ini yaitu jika daya serap individu mencapai $75 \%$ dan ketuntasan belajar klasikal mencapai $85 \%$ dan rata-rata persentase aktifitas guru, kemampuan psikomotor serta afektif berada pada kategori baik.

Prosedur penelitian tindakan kelas ini dilakukan dua siklus melalui 4 tahap yaitu: tahap perencanaan (planing), tahap tindakan (action), tahap pengamatan (observer), tahap refleksi (reflect). Pelaksanaan tindakan dilaksanakan dalam dua siklus, masing-masing siklus terdiri dari dua pertemuan. Pada tahap perencanaan tindakan dilakukan kegiatan merumuskan tujuan pembelajaran, menyiapkan materi sesuai dengan kurikulum, melaksanakan studi awal ke lokasi perekonomian, menyiapkan skenario kegiatan yang akan dilakukan, menyiapkan tata-tertib pelaksanaan karyawisata, menyusun RPP, membuat lembar observasi, menyusun lembar pengamatan karyawisata, menghubungi guru pemandu dan narasumber.

\section{HASIL DAN PEMBAHASAN}

Penelitian Tindakan Kelas ini dilakukan dengan dua siklus. Peneliti mengelompokan kegiatan pembelajaran tersebut menjadi 9 langkah pokok yang masing-masing langkah terdiri dari beberapa kegiatan guru. Langkah pertama, guru mengajak siswa mengingat kembali pelajaran yang pernah 
Ability : Journal of Education and Social Analysis

Volume 2, Issue 3, Juli 2021

Page : 108-115

diberikan pada pertemuan sebelumnya melalui pertanyaan apersepsi disertai dengaan tanya jawab tentang sistem pemerintahan desa. Langkah kedua, guru memotivasi siswa dalam membuat kaitan materi pelajaran yang akan dipelajari dengan peristiwa-peristiwa yang terjadi di masyarakat melalui pertanyaanpertanyaan berkaitan dengan sistem pemerintahan desa. Langkah ketiga guru mengemukakan tujuan pelajaran yang akan dipelajari dan menentukan kegiatan yang akan dilakukan bersama siswa.

Langkah keempat, guru mengemukakan tata-tertib selama kegiatan karyawisata berlangsung, membagi kelompok dan membagi lembar pengamatan karyawisata. Langkah kelima adalah melakukan observasi terhadap obyek sasaran belajar lalu mendeskripsikannya dalam bentuk kalimat, gambar dan sebagainya. Langkah keenam adalah melakukan wawancara dengan narasumber dan tanya jawab dengan guru dan guru pemandu kemudian menyuruh siswa bersama kelompoknya mencatat informasi yang disampaikan secara lisan oleh narasumber, guru dan guru pemandu pada lembar pengamatan karyawisata yang telah disediakan. Langkah ketujuh adalah menyuruh siswa melaporkan hasil pengamatan karyawisata dan membuat rangkuman. Langkah kedelapan adalah melakukan evaluasi proses dan hasil Sedangkan langkah kesembilan adalah melakukan tindak lanjut berupa pemberian tugas yang sifatnya memperkaya hasil karyawisata Selama mengikuti proses pembelajaran, guru memberikan penilaian kepada siswa yang meliputi penilaian proses dan hasil belajar siswa. Semakin baiknya langkah pembelajaran yang digunakan akan semakin tinggi hasil belajarnya.

Data hasil penelitian adalah sebagai berikut Pelaksanaan Siklus I masih kurang baik, hal ini terbukti dengan masih rendahnya hasil belajar dan persentase proses pembelajaran yang dilakukan guru dan siswa, serta ketuntasan pada penilaian hasil yang dicapai siswa, sehingga masih perlu diperbaiki pada siklus II. Hasil pelaksanaan tindakan siklus II terjadi peningkatan yang cukup baik sehingga peneliti mengakhiri penelitian tindakan kelas ini. Berikut Hasil Siklus I-II:

Tabel 1. Deskripsi Hasil Pengamatan Siklus I dan II

\begin{tabular}{|l|l|c|c|c|c|}
\hline \multirow{2}{*}{ No } & \multirow{2}{*}{ Aspek Pengamatan } & \multicolumn{2}{|c|}{ Siklus I } & \multicolumn{2}{c|}{ Siklus II } \\
\cline { 3 - 6 } & & $\%$ & Kategori & $\%$ & Kategori \\
\hline 1 & Aktifitas Guru & 70,00 & Cukup & 86,00 & Baik \\
\hline 2 & Aktifitas Siswa & 68,00 & Cukup & 82,00 & Baik \\
\hline 3 & Hasil Belajar & 67,67 & Cukup & 83,19 & Baik \\
\hline 4 & Ketuntasan & $64 \%$ & Cukup & $89 \%$ & $\begin{array}{c}\text { Sangat } \\
\text { baik }\end{array}$ \\
\hline
\end{tabular}




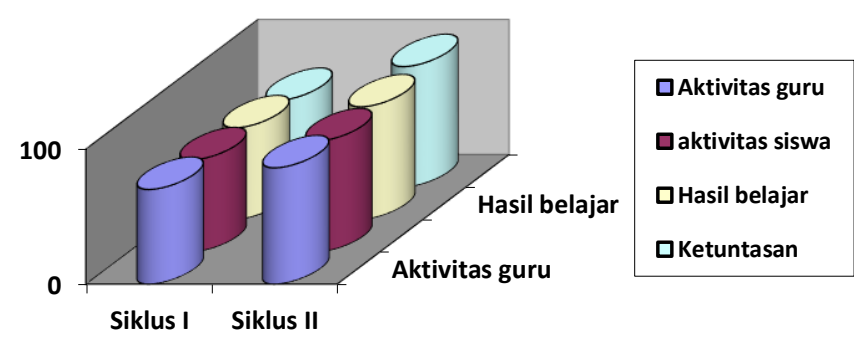

\section{Gambar 1. Hasil Siklus I dan Siklus II}

Berdasarkan Tabel, penggunaan metode field trip sangat membantu siswa sekolah dasar dalam meningkatkan hasil belajar siswa dalam pembelajaran IPS tentang sistem pemerintahan desa. Hambatan atau kendala yang dihadapi dalam penelitian ini antara lain: (1) siswa terlihat kurang aktif dalam melakukan tanya jawab dengan narasumber, guru dan guru pemandu karena kegiatan sering didominasi oleh siswa yang pandai, (2) membutuhkan pengawasan yang ekstra dari guru dalam mengawasi kegiatan anak di lapangan agar unsur belajar lebih diutamakan daripada unsur bermain/ rekreasi, (3) diperlukan motivasi dari guru secara terus menerus agar siswa lebih aktif dalam melakukan kerja kelompok, (4) guru biasanya agak kesulitan dalam membagi waktu kegiatan dilapangan.

Permasalahan ini dapat diatasi dengan solusi pembelajaran diantaranya: (a) Memberi kesempatan kepada siswa yang kurang aktif untuk mengemukakan pendapat dan bertanya kepada guru, guru pemandu dan saat berwawancara dengan narasumber sesuai pertanyaan yang telah disusun di rumah, (b) Membuat aturan tata-tertib yang tegas selama kegiatan pembelajaran berlangsung dengan memberi hukuman maupun hadiah. Selain itu guru mengatur posisi duduk danformasi barisan kelompok saat berada di obyek karyawisata dengan tujuan lebih mudah dalam pengawasan, (c) Memberikan motivasi yang ekstra saat siswa kerja kelompok dan ketika mempresentasikan hasil pengamatannya. Pengisian dan presentasi hasil pengamatan karyawisata dilakukan secara bergantian oleh anggota kelompok. Dengan demikian setiap siswa akan memberikan peranan dan kontribusi yang sama dalam kelompoknya, (d) Menyusun dan mengatur jadwal pembagian waktu kegiatan pembelajaran dengan matang

Metode field trip (karya wisata) sebagai salah satu metode pembelajaran mempunyai beberapa kelebihan, antara lain sebagai berikut: a) Siswa dapat mengalami langsung kegiatan yang berlangsung di lokasi field trip (karya wisata), b) siswa dapat menemukan sumber informasi pertama agar dapat memecahkan persoalan yang di hadapi, c)mendorong siswa menjadi lebih 
Page : 108-115

termotivasi dalam proses pembelajaran, d) membuat materi pembelajaran di kelas lebih relevan dengan kenyataan, karena siswa dibawa secara langsung ke sumber informasi dan e) siswa memperoleh pengetahuan dan pengalaman yang terintegrasi Hamdani (2012: 273)

Sedangkan kekurangan dari metode pembelajaran field trip menurut Hamdani (2012: 273) adalah sebagai berikut: pertama, karena dilakukan di luar sekolah dan jarak yang cukup jauh, diperlukan tranpor yang mahal dan biaya yang mahal; kedua, menggunakan waktu yang lebih panjang dari pada jam sekolah; kemudian yang ketiga, biaya yang tinggi kadang-kadang tak terjangkau oleh siswa sehingga memerlukan bantuan dari sekolah.

\section{KESIMPULAN}

Berdasarkan hasil analisa data dan pembahasan dapat diambil kesimpulan bahwa : Pembelajaran IPS dengan penerapan metode pembelajaran field trip dapat meningkatkan hasil belajar siswa kelas IV SD Negeri 56 Aek Batu Kecamatan Torgamba tahun pelajaran 2021/2022.

\section{DAFTAR PUSTAKA}

Arends, R,I, 2007. Learning to Teach, Belajar untuk Mengajar buku 2, Terjemahan oleh Helly Prajitno Soetjipto, dan Sri Mulyantini Soetjipto, 2008, Yogyakarta, Pustaka Belajar.

Arikunto, S. 2008. Dasar - dasar Evaluasi Pendidikan (Edisi revisi), Jakarta: Bumi Aksara

Abimanyu, Soli, dkk. 2008. Strategi Pembelajaran. Jakarta: Direktorat Jendral Pendidikan Tinggi Departemen Pendidikan Nasional.

Batic, Janja. 2011. The Field Trip as Part of Spatial (Architectural) Design Art Classes. Online. Tersedia di www.dlib.si.pdf [accessed 21/04/2015]

Hamdani. 2012. Strategi Belajar Mengajar. Bandung : Pustaka Setia. 